\title{
The VIelung rumal|ayas
}

Regional Challenges and Local Impacts

of Climate Change on Mountalin

Ecosystems and Livelihoods

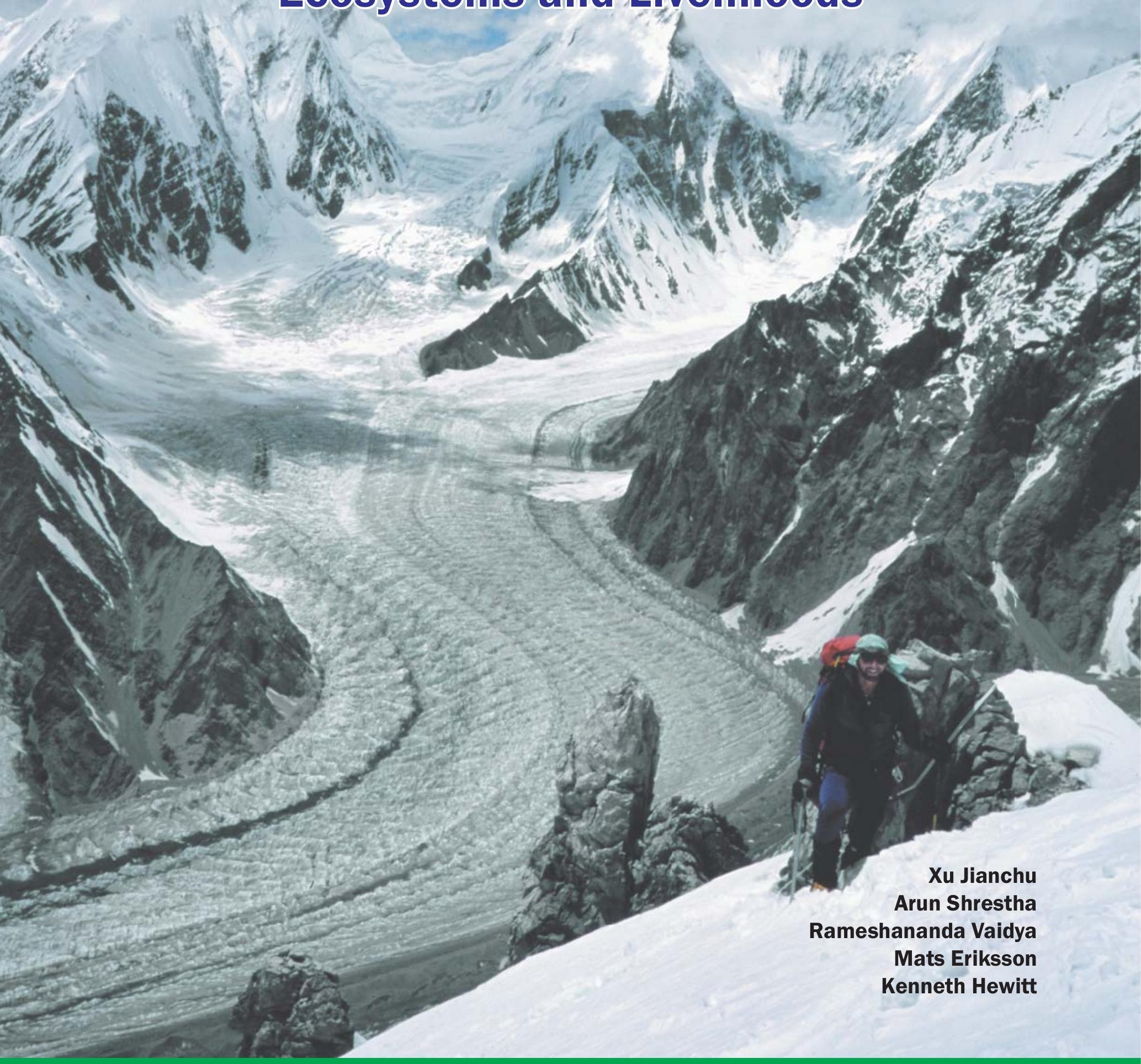

\section{Technical Paper}




\section{About ICIMOD}

\section{International Centre for Integrated Mountain Development}

The International Centre for Integrated Mountain Development (ICIMOD) is an independent 'Mountain Learning and Knowledge Centre' serving the eight countries of the Hindu Kush-

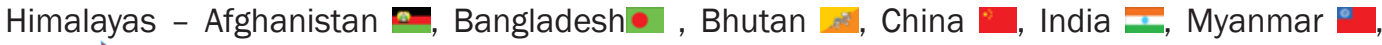
Nepal $\mathbf{B}$, and Pakistan IC - and the global mountain community. Founded in 1983, ICIMOD is based in Kathmandu, Nepal, and brings together a partnership of regional member countries, partner institutions, and donors with a commitment for development action to secure a better future for the people and environment of the extended Himalayan region. ICIMOD's activities are supported by its core programme donors: the governments of Austria, Denmark, Germany, Netherlands, Norway, Switzerland, and its regional member countries, along with over thirty project co-financing donors. The primary objective of the Centre is to promote the development of an economically and environmentally sound mountain ecosystem and to improve the living standards of mountain populations. 


\section{The Melting Himalayas Regional Challenges and Local Impacts of Climate Change on Mountain Ecosystems and Livelihoods}

Xu Jianchu, Arun Shrestha, Rameshananda Vaidya, Mats Eriksson, and Kenneth Hewitt

\section{ICIMOD Technical Paper}




\section{Copyright $\odot 2007$}

International Centre for Integrated Mountain Development (ICIMOD)

All rights reserved

\section{Published by}

International Centre for Integrated Mountain Development

G.P.O. Box 3226

Kathmandu, Nepal

\section{ISBN 9789291150472}

\section{Editorial team}

Greta Pennington Rana (Consultant Editor)

A. Beatrice Murray (Senior Editor)

Dharma R. Maharjan (Layout Design)

\section{Printed and bound in Nepal by}

Quality Printers Pvt. Ltd

Kathmandu

\section{Reproduction}

This publication may be reproduced in whole or in part and in any form for educational or non-profit purposes without special permission from the copyright holder, provided acknowledgement of the source is made. ICIMOD would appreciate receiving a copy of any publication that uses this publication as a source.

No use of this publication may be made for resale or for any other commercial purpose whatsoever without prior permission in writing from ICIMOD.

\section{Note}

The views and interpretations in this publication are those of the author. They are not attributable to ICIMOD and do not imply the expression of any opinion concerning the legal status of any country, territory, city or area of its authorities, or concerning the delimitation of its frontiers or boundaries, or the endorsement of any product. 


\section{Contents}

Acknowledgements

Abbreviations and Acronyms

iv

Summary

Introduction

1

Warming, Glacier Loss, and Changing Environments

Projected Future Trends and Impacts

7

Conclusion

9

Policy Recommendations

Bibliography 


\section{Acknowledgements}

Deepak Gyawali, from Nepal, and Bruno Messerli, from Switzerland, provided critical reviews. Thanks also are due to Alton Byers from the USA; Li Zheng, Yongping Yang and Shichang Kang from China; Jian Liu from the Intergovernmental Panel on Climate Change (IPCC), Geneva; R.K. Mazari from India; Ahsan Uddin Ahmed from Bangladesh; and John Dore from Thailand for comments. Thanks for their great support, particularly to Andreas Schild for his review and encouragement and to Ms. Li Qiaohong from the Kunming Institute of Botany, Chinese Academy of Sciences, for the literature study. This review is part of the BRAHMATWINN Project, 6th EU Framework Programme.

\section{Abbreviations and Acronyms}

$\begin{array}{ll}\text { CDM } & \text { clean development mechanism } \\ \text { GLOF } & \text { glacial lake outburst flood } \\ \text { ICIMOD } & \text { International Centre for Integrated Mountain Development } \\ \text { IWRAM } & \text { integrated water resource allocation and management } \\ \text { NAPAs } & \text { national adaptation plans of action } \\ \text { NPP } & \text { net primary productivity } \\ \text { PES } & \text { payment for environmental services } \\ \text { RCMs } & \text { regional climate models }\end{array}$

